\title{
The golden-backed uacari on the upper Rio Negro, Brazil
}

\author{
Adrian Barnett and Aléxia Celeste da Cunha
}

The golden-backed uacari Cacajao melanocephalus ouakary is one of South America's least-known monkeys. Listed as Vulnerable by the IUCN, it lives in remote areas of north-western Amazonia, as yet relatively unaffected by ecologically disruptive economic and technological activities. It inhabits swamp forests on black-water rivers during the main fruiting season and may move to dry land forests at other times of the year. The authors' survey showed that the animal was still common in the vicinity of subsistence communities, but is subject to heavy hunting pressure. Although the political situation in the area and the region's remoteness make it difficult to implement conservation plans, the authors propose a possible basis for a conservation plan for the golden-backed uacari and its habitat.

\section{The habitat}

The Amazon basin has three types of rivers; clear-water, black-water and white-water. White-water rivers originate on the eastern slopes of the Andes and gain their café au lait colour from sediment eroded from a geologically young formation. Black-water and clearwater rivers flow over the much older Guyana Shield, whose rocks are no longer rich in erodable deposits or soluble minerals (Meggers, 1971). So nutrient-poor are these waters that a hydrologist described the Rio Negro as 'slightly contaminated distilled water' (Goulding et al. 1988). Such rivers have a high humus content and are dark brown in colour, but the lack of suspended silt denies black-water rivers the complex system of creeks, islands and levées that form on white-water river margins (Ayres, 1986, 1989). Instead, low-lying areas slope gently towards higher ground (Goulding et al., 1988).

In Amazonia river levels may vary on an annual cycle by as much as $11 \mathrm{~m}$. Forests on high ground are never inundated and are termed terra firme, whereas those in lower areas may be flooded continuously for as long as 9 months. Those fringing white-water rivers are termed varzea, those along black- water rivers igapó (Prance, 1979).

Varzea and igapó are the only forest types in the world where fish are the major agents of fruit dispersal and predation (Goulding et al., 1988). Hence, most igapó and varzea trees fruit during the period of inundation (Revilla, 1981). This also has important consequences for the other denizens of the flooded forests.

The genus Cacajao is unique among Neotropical primates in possessing a very short tail, less than one-third of the combined head and body length. This is most unusual in an arboreal animal. There are two species in the genus, Cacajao calvus, the bald uacari and Cacajao melanocephalus, the black-headed uacari. C. calvus has four subspecies (calvus, rubicundus, novaesi and ucayalii); $C$. melanocephalus has two: the black-backed uacari (C. m. melanocephalus) and the golden-backed uacari (C. m. ouakary) (Hershkovitz, 1987).

C. $m$. ouakary occurs principally along the upper Rio Negro and its tributaries. Its eastern limit is the town of Barcelos in Brazil, its western limit apparently the confluence of the Apaporis and Guaviare rivers in Colombia. Its southern boundary is the northern bank of the Japura and its northern limits the Guaviare in Colombia. C. m. melanocephalus occurs in Venezuela between the Serra da Neblina and 
the Orinoco river. All records are from blackwater rivers. Figure 1 gives distributions of the various uacaris. Cunha and Barnett (1989) provide a bibliography for the genus.

Both species of uacari are listed as Vulnerable (Thornback and Jenkins, 1982) and appear on Appendix 1 of CITES. $C$. melanocephalus appears on the Brazilian Threatened Species List and is protected by law in Colombia. It is included in the 1977 US Endangered Species Act.

In 1982, Rylands and Mittermeier wrote 'Cacajao is the least known of all Neotropical primates'. The work of Marcio Ayres has gone a long way towards rectifying this for $C$. calvus and the laurels of this dubious honour must now rest with C. melanocephalus alone. In 1973, Russell Mittermeier conducted a 4-month sta- tus survey of the genus (Mittermeier and Coimbra-Filho, 1977). In 1976 A. Rylands conducted a survey on the upper Rio Negro and obtained information on C. melanocephalus. Hernandez-Camacho and Cooper (1976) reported on the status of $C$. melanocephalus in Colombia. T. Defler is studying the species on the Rio Apaporis in Colombia (R. Mittermeier, pers. comm.). Here we report on a preliminary survey of C. melanocephalus ouakary on the upper Rio Negro, Brazil.

\section{The study}

We undertook a preliminary survey of the golden-backed uacari in the São Gabriel da Cachoeira (SGC) region of the upper Rio

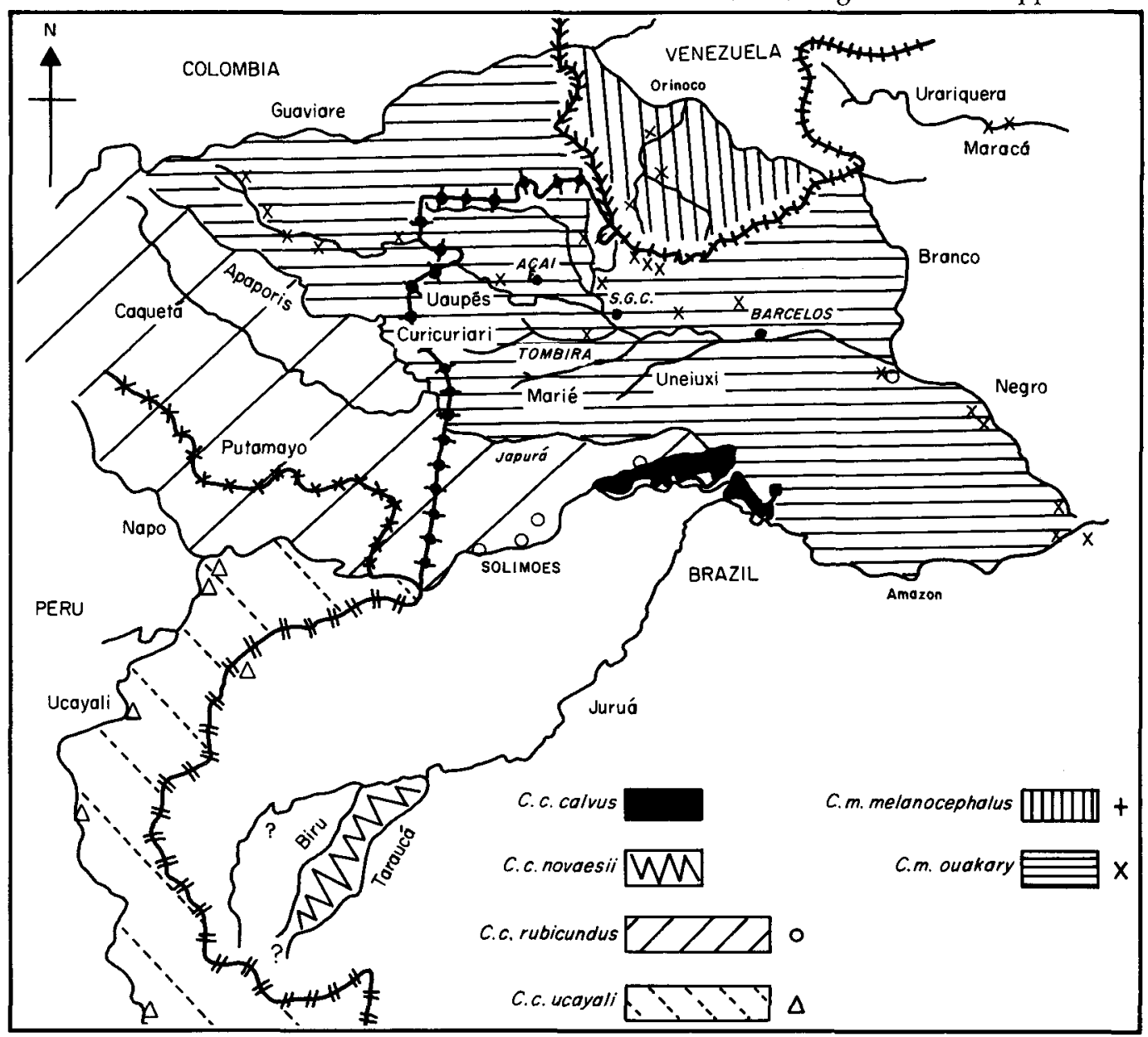

Figure 1. Map of the Amazon basin showing the distribution of the species of uacari (after Hershkovitz, 1987). 
Negro between May and July 1989. We also conducted field surveys on the Rio Curicuriari and the Rio Uaupés and conducted interviews in communities in the study area.

The questionnaire used in communities had 66 items and took about 2 hours to complete. It was designed to provide information on the sociology, economy, hunting practices and attitudes to primates of each community. The format followed recommendations in Moser (1958), Oppenheim (1966) and Schofield (1969). The questions were carefully worded to avoid ambiguity and 14 were specifically about the uacari. A shorter form was used in SGC. Reliability of informants was crosschecked using photographs of Amazonian monkeys, several of which were known not to occur in the region. Two field study sites were set up, one beyond Tombira, the last village on the Rio Curicuriari, the other near the village of Açai on the Rio Uaupés. Studies at these sites were augmented with observations of riverside vegetation. Travel to and from study sites was made with a motor-powered aluminium canoe loaned by the Special Frontier Batallion, Brazilian Army, and crewed by two soldiers. Surveys were carried out using specially cut trails on dry land and from canoes. We walked $34 \mathrm{~km}$ of trails at Curicuriari and paddled $39 \mathrm{~km}$. Standard trails were not used at Açai but 41.2 hours were spent there searching for uacaris.

\section{Indigenous impacts and attitudes}

Twenty-two interviews were conducted, six on the Curicuriari, four on the Uaupés and 12 in the SGC. Interviewees in SGC were hunters, gold-miners or river traders, some residents and others transient. On rivers the head man in each visited community was interviewed, with additional comments from other village members being noted. All were long-term residents with an intimate knowledge of the local forests.

All but one of the riverine communities had firearms. After fish, bushmeat is the most important source of protein for these communities. Men hunted at least once a week and more often if fishing gave low yields. Domestic animals, mostly ducks and chickens and occasionally pigs, are kept but these are eaten only in times of dire necessity.

All nine species of monkey reported to occur in the survey area (see Table 1) formed part of the local diet but C. m. ouakary was eaten most frequently. All primates are hunted opportunistically, being shot at whenever seen. There appeared to be no closed season nor any time when monkeys were hunted more intensely. Local beliefs can influence hunting patterns; Peres (1990) reported that hunters sometimes excluded $C$. $c$. novaesi because it looked too human. In Suriname, Mittermeier (1977) found a complex system of taboos against eating various types of monkey. This was not the case in our study area. Snakes were the only vertebrates reported as not being eaten-though preferences were given against eating Alouatta, Aotus, Saimiri and Callicebus. Peres (1990) noted that self-imposed restrictions on wild-caught dietary items generally occur in communities where protein sources are attainable with comparative ease. This is not the case on black-water rivers (Meggers, 1971).

Elsewhere in South America carcasses of hunted monkeys also provide products for medicinal and ornamental use (Mittermeier and Coimbra-Filho, 1977). Direct questions about this produced negative answers and we saw no artefacts made from monkey parts. Cebus apella was the only species reported to raid crops; it appeared to be more of a nuisance than a problem. There appears to be a small, non-commercial, trade in baby monkeys for pets. Animals sold in this way include the golden-backed uacari.

In summary, in the areas surveyed monkeys (including the uacari) are neither revered nor reviled, simply hunted.

Because all our visits to communities were short, we were unable to obtain any information on the frequency with which uacaris or other monkeys were hunted. Nor could we use 'remote' techniques, such as rummaging about in kitchen middens. Waste in these riverine communities is usually thrown directly into the river. Nevertheless, the frequency with 
which we encountered game animals, such as tapir Tapirus terrestris, paca Agouti paca and cracids (Mitu mitu, Crax spp. and Penelope spp.) indicated that, for the present at least, overhunting is not a problem in the area surveyed.

Elsewhere on the Rio Negro, C. m. ouakary has been reported as being eaten occasionally and hunted as bait for fish, turtles and forest cats (Mittermeier and Coimbra-Filho, 1977). This does not appear to be the case in our study sites. Examination of 32 skins of locally killed jaguar Felis onca, puma F. concolor, ocelot $F$. pardalis and margay $F$. weidii indicated they had all been shot, not trapped live. This supports the emphatic denials of local people about the use of the uacari as bait.

A possible explanation of the difference lies in the virtual absence of other large species of monkey in the surveyed region. We did not see spider monkey Ateles belzebuth or woolly monkey Lagothrix lagotricha on the Curicuriari or Uaupés rivers; and received only scattered reports, all of which referred to their rarity at these locations. Both these species are large (Ateles about $8 \mathrm{~kg}$, Lagothrix up to $10 \mathrm{~kg}$ ), gregarious and have, reportedly, tasty flesh. They are avidly hunted wherever they occur (Hernandez-Camacho and Cooper, 1976; Mittermeier and Coimbra-Filho, 1977; Peres, 1990). In their absence, the uacari and the red howler Alouatta seniculus at $4 \mathrm{~kg}$ and $8 \mathrm{~kg}$ respectively, are the two largest monkeys. Howlers are eaten, but are not favoured because their flesh is reported to have an unpleasant taste and/or smell. People are also reported to find their botflies repulsive (Mittermeier and Coimbra-Filho, 1977). This leaves the uacari squarely in the firing line.

\section{Ecology of the golden-backed uacari}

Five contacts were made with this monkey. One on the Rio Curicuriari, three near Açai on

Table 1. Primate field survey

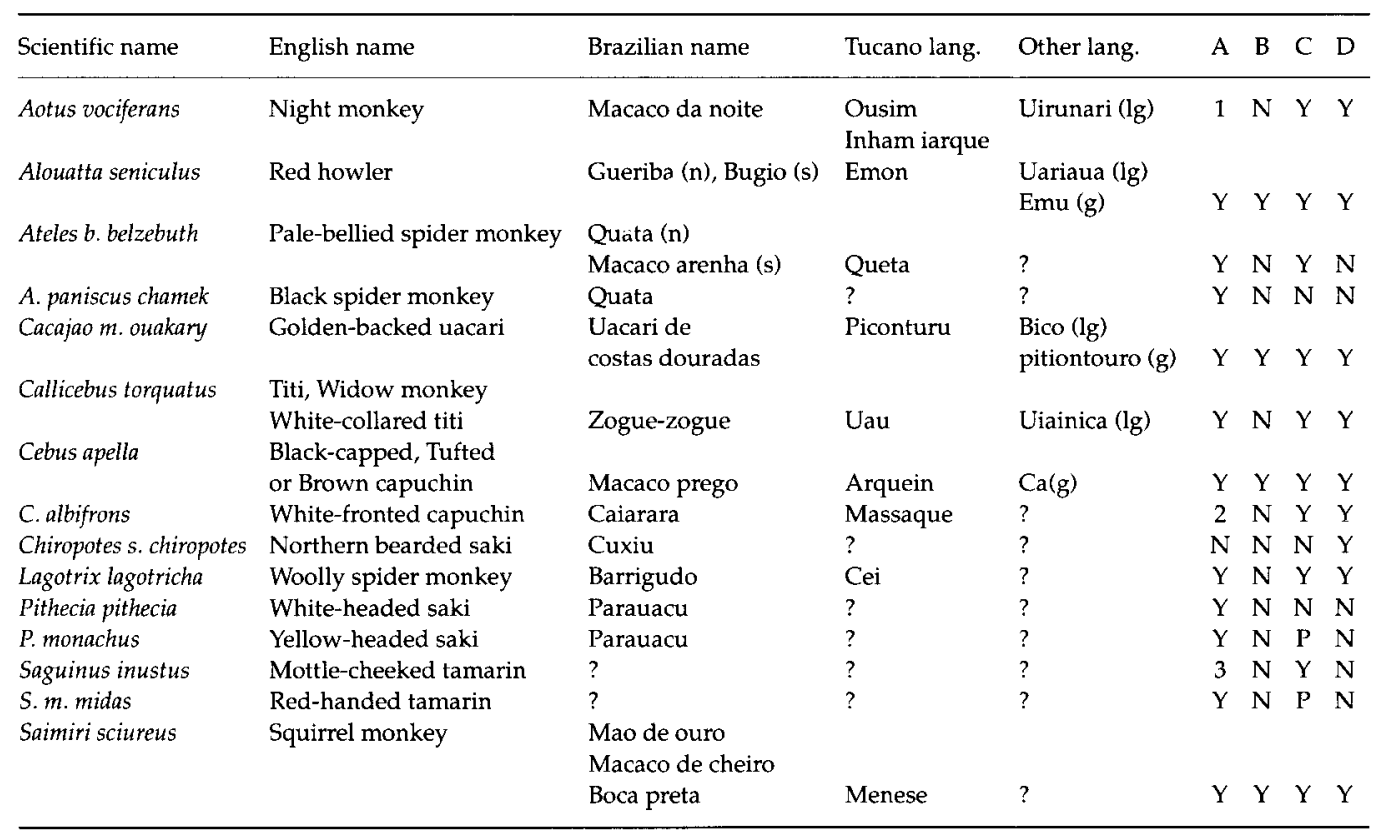

General notes: $\mathrm{n}$ \& s in Brazilian names refers to names used in north and south; $1 \mathrm{~g} \& \mathrm{~g}$ in other languages =lingua gerel. Guarana.

$\mathrm{A}=$ photograph of animal used in field study. $\mathrm{B}=$ observed in area. $\mathrm{C}=$ expected in area. $\mathrm{D}=$ reported in area.

Notes from A: 1: Photo of A trivirgatus used; 2: Photo of Cebus albifrons used; 3: Photo of Saguinus m. midas used.

Nomenclature: for Aotus follows Hershkovitz (1983); for Cacajao, Hershkovitz (1987); for Ateles, (Konstant, Mittermeier and

Nash (1985); all other genera, Mittermeier and Coimbra-Filho (1981). 
the northern bank of the Uaupés and one on its southern bank, opposite Açai. The group at Curicuriari was spotted at dusk, moving low and fast in dense riverside vine tangles. The group had been panicked by the sound of our motor and little useful information was obtained. While based at Açai we were able to use Indian canoes. This allowed us to listen for calls and the sounds of fruits falling into the water and then paddle quietly towards the monkeys. Between five and 22 uacari were seen in each of the five contacts, but calls and vegetation movements indicated that there were more animals in the vicinity. Local informants had put maximum group sizes at about 50 animals. Groups appeared to be multimale. Two young infants were seen riding on their mothers' backs and three independently locomoting juveniles were also seen. If developmental rates and stages are comparable to those observed by Fontaine (1981) for captive C. c. rubicundus, this would place parturition in January/March, at the onset of the annual igapó inundation.

Individuals were seen feeding in trees of uaraba Swartzia polyphylla, abiu de igapó Gomphiluma gomphifolium and cupa-uba Labatia macrocarpa. Our guide at Açai said that he had also seen C. m. ouakary eating fruits of macucu Aldinia latifolia, which had finished fruiting at the time of our visit. Other informants said the uacari also ate the fruits of macaranduba Manikilara huberi and seringa (Hevea sp.). With the exception of Gomphiluma and Aldinia, all of these have fruits with hard husks. Ayres (1989) reports that $C$. calvus specializes in this class of fruit.

All Uaupés contacts were made in riverine igapó, an open form of igapó with well-spaced large trees and a canopy $15 \mathrm{~m}$ above the highwater level, which occurs along the margins of major watercourses. Creek igapó, much lower and denser, composed mainly of shrubs and restricted to smaller watercourses, was searched without success at both sites; although local informants reported that the monkey does occur there.

Our short survey was made during the middle of the wet season. Twelve out of 22 interviewees gave information on the seasonal

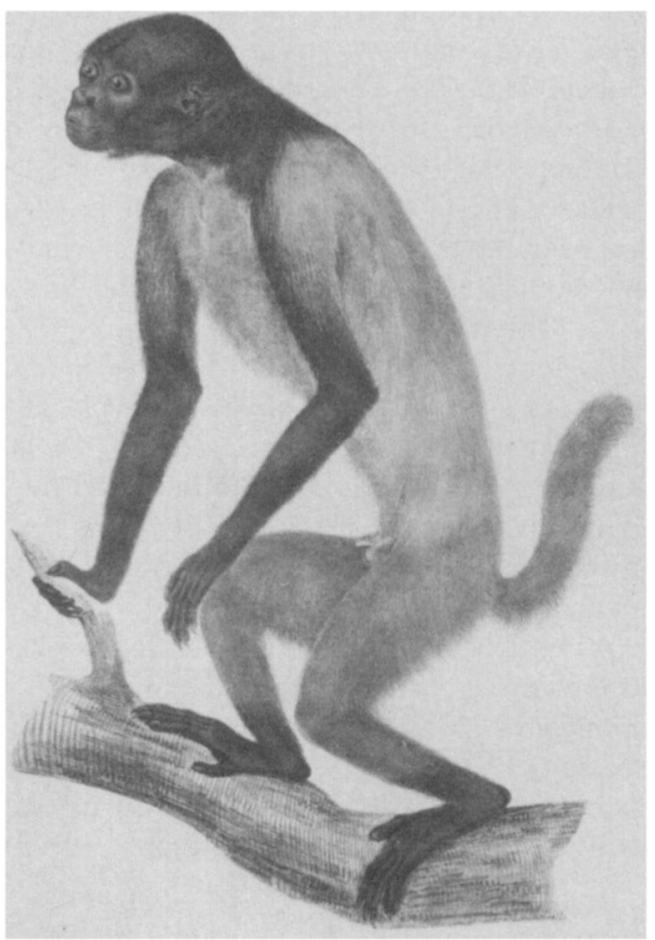

A golden-backed uacari.

distribution of the uacari. In all but one case we were told that C. m. ouakary moves out of igapó during the dry season. Three informants said it went to terra firme forests, two said it left igapó but did not know where to, the remainder did not specify. Although this information agrees with reports given to Russell Mittermeier elsewhere in the animal's range (Mittermeier and Coimbra-Filho, 1977), it has yet to be confirmed or quantified by field studies. As such it should be treated with caution.

\section{Status of the golden-backed uacari}

Figure 2 shows the areas we visited and those additional areas for which we obtained reliable information on the uacari's presence and status. At most of these localities the species was described as common. Our observations on the Uaupés certainly suggest that this was the case there. Communities on the Uaupés are of Tukano indians, those on the Curicuriari are either Tucanos or of long-established 
Caboclos (non-indian subsistence farmers). From interviews and observations there appears to be very little difference in the lifestyle of the two or in their relationship with the natural environment. In remote areas such communities are generally spaced one to two days paddling apart. Hunting areas are well known and generally well respected. Communities number 23-86 people and were reported not to have expanded greatly in the last few years. Communities of this nature generally have a sustainable impact on local wildlife (Mittermeier, 1977). Chernela (1989) reports the Tukano of the Uaupés have taboos on the cutting of igapó forests.

The situation is somewhat different on the upper Rio Negro. Here many new settlements have sprung up in the last few years and are closer together than those on the Uaupés and Curicuriari. Hunted meat is an important protein source for these communities too. A number of medium-sized ranches were also seen (but not visited). The establishment of these involves clear-felling of the forest. Mittermeier (1987) reported that many people in towns will not eat monkey as it is regarded as 'primitive' to do so. This does not appear to be the case in SGC. A number of well-off and welleducated citizens said that they hunted monkey, others that they ate it when available. Hunting appeared to depend on individual initiative. Market hunting can be very disruptive to primate populations (Mittermeier, 1989), but none was seen in SGC.

Older residents of SGC said that monkeys (including the golden-backed uacari) used to be plentiful in the immediate region but were now rare. They blamed overhunting. In summary, it appears that populations of $C$. $m$. ouakary are abundant in those areas of the upper Rio Negro river system where a traditional life-style predominates and human population density is low. It is endangered with local extinction in the vicinity of connurbations.

\section{The future}

Rylands and Mittermeier (1982) noted that the Brazilian range of $C$. melanocephalus is the

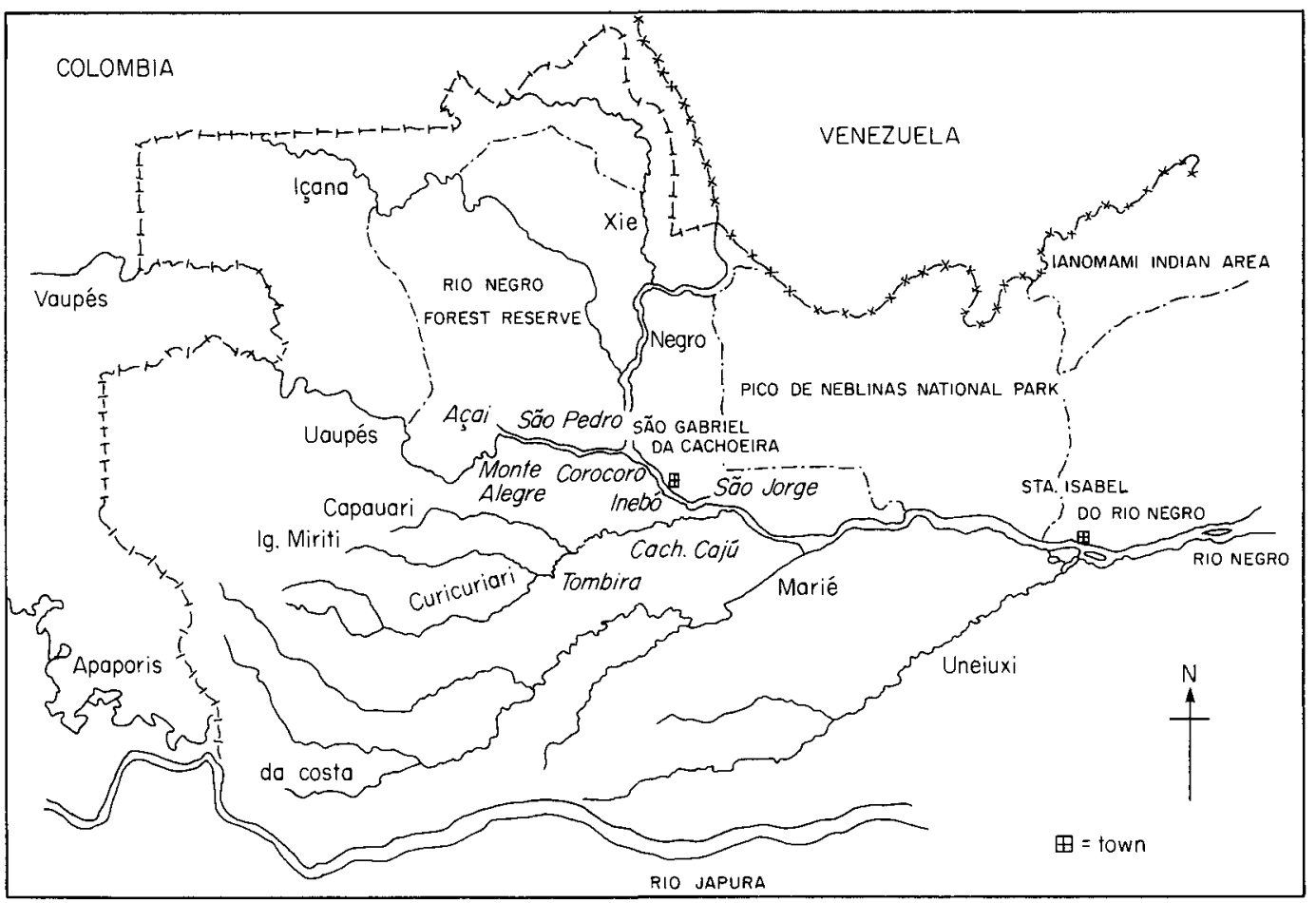

Figure 2. Detail of the São Gabriel da Cachoeira area. 
stronghold of the species. HernandezCamacho and Cooper (1976) described the species's status in Colombia as 'precarious'. Little is known about the situation in Venezuela, although Rudran and Eisenberg (1982) noted that C. m. melanocephalus has the most restricted range of any Venezuelan primate. Much of the known geographic range of Venezuela's black-backed uacari is in areas subject to intense illegal gold-mining. Given the potential of such activities for habitat destruction, and the almost complete dependency of miners on bushmeat for protein, this situation should be a cause for grave concern.

As far back as 1972 A. Coimbra-Filho called for urgent steps to be taken to set up conservation areas to protect the golden-backed uacari. Brazil still lacks any specific areas set aside for this purpose. The animal is said to occur in three protected areas (Thornback and Jenkins, 1982): Pico da Neblina National Park (Best, 1978), Jaú National Park (Rylands, 1990) and Maracá Ecological Station. The last is in Roraima State and far to the east of all other records (Figure 1). Nunes et al. (1988) do not list the uacari for Roraima and one of us (ACDC) did not see or hear of it during a 13month residency at the station. We therefore follow Hershkovitz (1987) in considering this record to be a mistake. Of the other two protected areas, Pico de Neblina is regarded as one of the most endangered protected areas in the Brazilian Amazon (Rylands, 1990). The area has missions, roads and at least 1000 illegal gold miners operating inside the park boundaries.

The implementation of any form of conservation planning in the SGC region is fraught with political, social, economic and logistic difficulties. The region is one of the least developed in Amazonia. This may please some passing conservationists but fails to do the same to any of the local residents. Local politicians make repeated calls for progress, investment and development. The SGC region is isolated. There are no roads to it and food and durables must be flown in or brought up by riverboat. This adds to the costs of basic articles and fuels demands for locally based development.
Politically the situation in the region is best described as somewhat fluid. A strong military presence, a large and politically aware indian community, illegal miners and rumoured 'cocaineros' provide a range of interest groups whose diverse predilections would be difficult to reconcile in any overall management plan.

The golden-backed uacari is a habitat specialist. The probable annual movement to terra firme does not alter that, it simply adds a new dimension to the conservation planning for the species. It appears to require substantial areas of undamaged igapó with adjacent terra firme forest. The fact that interviewees said that it does not occur in small islands of mixed terra firme and igapó must also be taken into account by any management plan.

Data gathered by Rylands (1976) suggest that at the local scale the distribution of C. $m$. ouakary populations may be patchy. For example, he recorded it as absent from the Rios Padauiri and Ariraha. Both are adjacent to known localities for this monkey, but appear to lack suitable habitat. This too must be considered when attempting effective conservation proposals.

The Red Data Book sheet on C. melanocephalus includes the recommendation that an area between the Rios Curicuriari and Ineiuxi be set aside as a reserve. This is, presumably, based on the results of R. Mittermeier's 1973 survey, where $C$. melanocephalus was commonly found on the Cuiexi and Uneiuxi rivers. If implemented this would place this uacari's only specific refuge in between the areas of influence of the two largest towns in the region, SGC and Santa Isabel (Figure 2). We would suggest that considerations be given to the creation of such a reserve on the Rio Uaupés-possibly within the Açai region. This area is already a National Forest Reserve and, although this is a consumptive use category (Jorge Padua and Quintao, 1982), it might be possible to upgrade part of this $37,900 \mathrm{sq} \mathrm{km}$ to protect the primate and its environment.

The status of this region is at present undecided. On 22 June 1989 Indian communities on the Rio Uaupés held a meeting at the Taraqua Mission to decide if the immediate area will become an Indian Colony or an 
Indian Area. The differences are significant and complex, but integration of a conservation plan for the golden-backed uacari with either of these formats could benefit the monkey, the local communities, and the igapó forest upon which both are so largly dependent. The present small-scale agriculture and fishing-based lifestyle of the Tukano indians appears sustainable (Chernela, 1985). The area could probably support few other human activities; Santos et al. (1984) and Chernela (1989) have shown that soils in the region are amongst the poorest in the world

In co-operation with the Brazilian Institute for Conservation Research (Pronatura) and with assistance from Brazilian government agencies we hope to provide just such an option for consideration by the appropriate authorities, once our long-term studies of the golden-backed uacari and its igapó habitat have been completed. It is clear that such action is necessary. Part of the current development plans for the region include an extension of the BR 210. If completed this road would run within a few kilometres of the Açai study site. The ease with which such constructions can act as channels of colonization to previously unavailable areas has been well documented in Amazonia (Goodland and Irwin, 1975). Such events can have unfortunate environmental consequences because, as noted by Rylands and Mittermeier (1982), 'attitudes towards hunting can change quickly with an influx of new settlers'.

Differences in uses of C. m. ouakary in different parts of the Rio Negro system already occur; on the Uaupés it is a major food item, elsewhere it is used mainly for bait. As one of the two large monkeys in the SGC region the golden-backed uacari is vulnerable to increased hunting pressure, for whatever reason it occurs.

At present the golden-backed uacari appears to be very common on the upper Rio Negro, but if present trends continue it is uncertain how much longer this will continue to be the case.

\section{Acknowledgments}

We would like to thank General Thaumaturgo Vaz, Supreme Military Commander for Amazonia and
Colonel Dias Torres, commander of the 5th Special Frontier Batallion, São Gabriel da Cachoeira. We would like to express our gratitude to the men of the 5th Batallion and to all who helped us at INPA (Instituto Nacional de Pesquisas da Amazonia), Manaus, especially Marc van Roosmalen, Juan Revilla, Angelo dos Santos, Maria do Carmo and Francisco Collares. Also to Nelia Taminini, Paulo Ribiero and Colette Burch for their continued support. Anthony Rylands and two anonymous reviewers kindly read and commented on earlier versions of this text. This work was supported by grants from the Linnean Society, Royal Geographical Society, funds from a grant to Marc van Roosmalen from WWF-Netherlands and by personal financing. A copy of Project Uacari's preliminary report is available from the authors price $£ 7.50$ plus postage and packing.

\section{References}

Ayres, J.M.C. 1986a. The conservation status of the white uakari. Primate Conservation, 7, 22-26

Ayres, J.M.C. 1986b. Uakaris and Amazon Flooded Forest. PhD Thesis, University of Cambridge.

Ayres, J.M.C. 1989. Comparative feeding ecology of the Uakari and Bearded Saki, Cacajao and Chiropotes. Journal of Human Evolution, 18, 697-716.

Ayres, J.M.C. and Johns, A.D. 1987. Conservation of white uacaris in Amazonian varzea. Oryx, 21, 74-80.

Bartecki, U. and Heymann, E.W. 1987. Sightings of red uakaris, Cacajao calvus rubicundus, at the Rio Blanco, Peruvian Amazon. Primate Conservation, 8, 34-36.

Best, R.C., 1978. An evaluation of four potential national park sites within Brazilian Amazonia. A report on the mammals and birds. Unpublished report to IBDF, 6pp.

Chernela, J.M. 1985 Indigenous fishing in the neotropics: the Tukanoan Uanano of the blackwater Uaupes River Basin in Brazil and Colombia. Interciencia , 10, 78-86.

Chernela, J.M. 1989. Managing rivers of hunger: The Tukano of Brazil. Advances in Economic Botany, 7, 238-248.

Coimbra-Filho, A.F. 1982. Mamiferos amacados de extincao no Brasil. In Especies da Fauna Brasiliera Amacados de Extincao, pp. 13-98. Brazilian Academy of Sciences, Rio de Janeiro.

Cunha da, A.C. and Barnett, A. 1989. Project Uakari. First report: The preliminary survey. Part one: Zoology. Unpublished report to WWFNetherlands, 95pp.

Fontaine, R. 1979. Survey of the red uakary (Cacajao calvus rubicundus) in eastern Peru. Unpublished report to New York Zoological Society. 
Fontaine, R. 1981. The uakaris, genus Cacajao. In Ecology and Behaviour of Neotropical Primates (eds A. F. Coimbra-Filho and R. A. Mittermeier), pp. 443-493. Brazilian Academy of Sciences, Rio de Janeiro.

Fontaine, R. and Du Mond, F.V. 1977. The red ouakari in a semi-natural environment: potentials for propagation and study. In Primate Conservation (eds Prince Rainier of Monaco and G. H. Bourne), pp. 167-326. Academic Press, New York.

Goodland, R.J.A. and Irwin, H.S. 1975. Green Hell to Red Desert. Elsevier Publications, Amsterdam and New York.

Goulding, M., Carvalho, M.L. and Ferreira, E.G. 1988. Rio Negro: Rich Life in Poor Water. SPB Academic Publishing bv, The Hague.

Hernandez-Camacho, J. and Cooper, R.W. 1976. The non-human primates of Colombia. In Neotropical Primates: Field Studies and Conservation (eds R. W. Thorington and P. G. Heltne), pp. 35-69. National Academy of Sciences, Washington DC.

Hershkovitz, P. 1983. Two new species of night monkeys, genus Aotus (Cebidae, Platyrrhini): a preliminary report on Aotus taxonomy. Am. Journ. Primatol. 4, 209-243.

Hershkovitz, P. 1987. Uacaris, new world monkeys of the genus Cacajao (Cebidae: Platyrrhini). A preliminary review. Am. Journ. Primatol. 12, 1-53

Jorge Padua, M.T. and Quintao, A.T.B. 1982. A system of National Parks and Biological Reserves in the Brazilian Amazon. In National Parks, Conservation, and Development (eds J. A. McNeely and K. R. Miller), pp. 565-573. Proceedings of the World Congress on National Parks, Bali, Indonesia. Smithsonian Institution Press, Washington DC.

Konstant, W., Mittermeier, R.A. and Nash, S.D. 1985. Spider monkeys in captivity and in the wild. Primate Cons. 5, 82-109.

Meggers, B.J. 1971. Amazonia. Man and Culture in a Counterfeit Paradise. Aldine-Atherton, Chicago.

Mittermeier, R.A. 1977. Distribution, Synecology and Conservation of Surinam Monkeys. PhD Thesis, Harvard University.

Mittermeier, R.A. 1987. Effects of hunting rainforest primates. In Primate Conservation in the Tropical Rainforest, (eds C. W. Marsh and R. A. Mittermeier) pp. 109-146. Alan Liss inc., New York.

Mittermeier, R.A. and Coimbra-Filho, A.F. 1977. Primate conservation in Brazilian Amazonia. In Primate Conservation (eds Prince Rainier of Monaco and G. H. Bourne), pp. 109-146. Academic Press, New York.
Mittermeier, R.A. and Coimbra-Filho, A.F. 1981. Systematics: species and subspecies. In Ecology and Behaviour of Neotropical Primates 1(eds A. F. Coimbra-Filho and R. A. Mittermeier) pp. 29-110. Acad. Bras. Ciênc., Rio de Janeiro.

Moser, C.A. 1958. Survey Methods in Social Investigation. Heinemann, London.

Nunes, A.P., Ayres, J.M., Martins, E.S. and de Souza e da Silva, J. 1988. Primates of Roraima (Brazil). I: the northern part of the territory. Boletim do Museu Paraense Emilio Goeldi, Zoologia, 4, 87-100.

Oppenheim, A.N. 1966. Questionnaire Design and Attitude Measurement. Heinemann, London.

Peres, C.A. 1990. Effects of hunting on western Amazonian primate communities. Biological Conservation, 54, 47-59.

Prance, G.T. 1979. Notes on the vegetation of Amazonia III: the terminology of Amazonian forest types subject to inundation. Brittonia, 31, 26-38.

Revilla, J. 1981. Aspectos Floristicos $e$ Fitosocioecologicos da Floresta Inundavel (Igapo). Praia Grande, Rio Negro, Amazonas, Brazil. MSc Thesis, University of Amazonas and INPA, Manaus.

Rudran, R. and Eisenberg, J.F. 1982. Conservation status of wild primates in Venezuela. International Zoo Yearbook, 22, 52-58.

Rylands, A.B. 1976. The Distribution of Primates on the Rio Negro. Unpublished report, INPA, Manaus. 60 pp.

Rylands, A.B. 1990. Evaluation of the Current Status of Federal Conservation Areas in the Tropical Rain Forest of the Brazilian Amazon. Volume 2: National Parks. WWF-US, Washington, DC.

Rylands, A.B. and Mittermeier, R. A. 1982. Conservation of primates in Brazilian Amazonia. International Zoo Yearbook, 22, 17-37.

Santos, U. de Menezes, Bulcao Bringel, S.R., Bergamin Filho, H., Nazare Goas Ribeiro, M. and Bananeira, M. 1984. Rios da Bacia Amazonica I. Afluentes do Rio Negro. Acta Amazonica, 14, 222-237.

Schofield, M. 1969. Social Research. Temple Smith, London.

Thornback, J. and Jenkins, M. 1982. Mammal Red Data Book. Part 1. Threatened Mammalian Taxa of the Americas and Australasian Zoogeographic Region (excluding Cetacea). IUCN, Gland.

Adrian Barnett, Project Uakari, 38 Hill House Road, Streatham, London SW16 2AQ, UK.

Aléxia Celeste da Cunha, Pronatura, Rua da Quitanda, 20/4 andar, Rio de Janeiro, R.J., Brazil. 